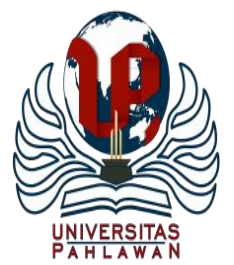

Edukatif : Jurnal Ilmu Pendidikan Volume 3 Nomor 5 Tahun 2021 Halm 2551 - 2562

EDUKATIF: JURNAL ILMU PENDIDIKAN

Research \& Learning in Education

https://edukatif.org/index.php/edukatif/index

\title{
Kebijakan Sistem Pendidikan Indonesia: Keterkaitan Dunia Sekolah dengan Dunia Kerja Sebuah Alternatif
}

\author{
Tan Gusli $^{1 凶}$, Nurhizrah Gistituati ${ }^{2}$, Sufyarma Marsidin ${ }^{3}$ \\ Universitas Negeri Padang, Indonesia ${ }^{1,2,3}$ \\ E-mail : gusli.tan@gmail.com ${ }^{1}$, gistituatinurhizrah@gmail.com ${ }^{2}$, Sufyarma@fip.unp.ac.id $^{3}$
}

\begin{abstract}
Abstrak
Keterkaitan dunia pendidikan dengan dunia kerja harus menjadi perhatian serius bagi sistem pendidikan Indonesia. Tujuan penelitian ini adalah sebagai sebuah alternatif terhadap problema tingginya tingkat pengangguran di Indoseia. Jenis penelitian ini adalah kualitatif deskriftif. pengumpulan data menggunakan sumber data primer yang diperoleh dari berbagai referensi, media online. Analisisnya adalah dengan melakukan kajian kajian literatur terhadap sistem pendidikan indonesia dan mencarikan solusi terhadap permasalahan dan menarik sebuah kesimpulan. Hasil penelitian menunjukkan bahwa perlunya penerapan program melalui perguruan tinggi sebagai lembaga pendidikan dengan (1) Perguruan tinggi harus mau melakukan riset ke dunia kerja. (2). Menjalin relasi atau mitra hubungan dengan banyak perusahan (3).Membuat bank data kebutuhan dunia kerja dan kelulusan. (4). Kewirausahaan dijadikan muatan lokal.
\end{abstract}

Kata Kunci: Sistem Pendidikan,Dunia Sekolah, Dunia Kerja.

Abstract

The relationship between the world of education and the world of work must be a serious concern for the Indonesian education system. The purpose of this study is as an alternative to the problem of the high unemployment rate in Indonesia. This type of research is descriptive qualitative. data collection using primary data sources obtained from various references, online media. The analysis is to conduct a literature review of the Indonesian education system and find solutions to problems and draw a conclusion. The results of the study indicate that it is necessary to implement the program through universities as educational institutions with (1) Universities must be willing to conduct research into the world of work. (2). Establish relationships or relationship partners with many companies (3). Create a data bank for the needs of the world of work and graduation. (4). Entrepreneurship is made local content.

Keywords: Education System, School World, Work World.

Copyright (c) 2021 Tan Gusli, Nurhizrah Gistituati, Sufyarma Marsidin

$\triangle$ Corresponding author

Email : gusli.tan@gmail.com

DOI : https://doi.org/10.31004/edukatif.v3i5.844

ISSN 2656-8063 (Media Cetak)

ISSN 2656-8071 (Media Online) 


\section{PENDAHULUAN}

Pendidikan merupakan konsep dasar dalam upaya pembentukan manusia (Syafril; Zen, 2017), maju mundurnya peradaban masyarakat dan negara sangatlah bergantung pada bagaimana kualitas pendidikan diselenggarakan oleh masyarakat atau negara tersebut, maka pendidikan merupakan hal pokok yang wajib di lakukan. Keberhasilan suatu negara juga selalu di ukur dengan seberapa maju tingkat pendidikannya (Isjoni, 2006). Sehingga perhatian mengenai pendidikan mau tidak mau dan tidak boleh tidak harus selalu tinggi. Dalam perjalan sejarah pendidikan Indonesia begitu banyak kritik akan mutu pendidikan terutama pendidikan tinggi. Kenapa demikian, salah satu yang menjadi sorotan adalah tidak pernah tuntasnya masalah pengangguran intelektual yang jumlahnya terus mengalami peningkatan. Dan tentu hal tersebut seakan menjadi pembuktian akan kebenaran mutu pendidikan dan pendidikan tinggi di Indonesia.

Tingkat Pengangguran di Indonesia terbuka mencapai 7,07 persen dari 138,22 juta angkatan kerja (Statistik, 2020). Artinya terdapat 9,77 juta penduduk pengangguran terbuka. Walaupun terjadi kenaikan Tingkat Partisipasi Angkatan Kerja (TPAK) sebanyak 0,24 persen poin menjadi 67,77 persen, terjadi penurunan pada jumlah penduduk yang bekerja. Berdasarkan klasifikasi tempat tinggal terdapat 8,98 persen pengangguran dari jumlah tersebut. Sedangkan untuk daerah perdesaan terdapat 4,71 persen penduduk. Dari data ini tingkat pengangguran di Indonesia sudah mencapai 2,56 juta penduduk dari 29,12 juta penduduk usia kerja.

Banyak asumsi yang bisa dimunculkan menjawab informasi tersebut, asumsi pertama tentu imbasnya covid 19, menyebabkan semakin pengangguran di Indonesia. Namun tentu tidak cukup rasanya sampai pada asumsi seperti ini. Covid 19 memang sangat berimbas pada meningkatnya pengangguran di Indonesia. Asumsi kedua tentu melirik pada akar permasahan kenapa pengangguran itu dari tahun ketahun semakin meningkat. Asumsi inipun bermunculan untuk menjawab akar permasalahan tersebut, apakah dari sisi buruknya kurikulum, rendahnya kualitas dosen, dan minimnya fasilitas dan sarana pendidikan, dan pertumbuhan kesempatan kerja yang kecil. Walaupun pada dasarnya permasalahan itu saling keterkaitan satu sama lain. Sehingga diperlukan wawasan baru mengenai pendidikan untuk bisa memahami permasalahan itu lebih dalam.

Memang dan jujur harus diakui bahwa akhir akhir ini lontaran kritikan terhadap sistem pendidikan Indonesia yang pada dasarnya mengatakan bahwa perluasan kesempatan belajar cenderung telah menyebabkan bertambahnya pengangguran tenaga terdidik dari pada bertambahnya tenaga produktif yang sesuai dengan kebutuhan lapangan kerja. Kritik ini tentu saja memiliki alasan tersendiri karena data sensus penduduk memperhatikan kecenderungan yang menarik bahwa proporsi jumlah tenaga penganggur lulusan pendidikan yang lebih tinggi ternyata lebih besar dibandingkan dengan proporsi penganggur dari lulusan yang lebih rendah. dalam bahasa lain persentase jumlah pengangguran lulusan sarjana lebih banyak apabila dibandingkan dengan persentase jumlah pengganggur tamatan sekolah menengah atas atau jenjang pendidikan yang lebih rendah.

Namun, apakah kritik yang dilontarkan tersebut benar seluruhnya, tentu saja jawabannya belum semuanya bisa dianggap benar karena cara berfikir yang digunakan dalam memberikan asumsi terhadap data empiris tersebut cenderung menyesatkan. Cara berfikir yang sekarang berlaku seolah-olah hanya memperhatikan pendidikan sebagai satu-satunya variabel yang menjelaskan masalah pengangguran. Cara berfikir seperti cukup berbahaya, bukan hanya berakibat pada penyudutan sistem pendidikan, tetapi juga cenderung menjadikan pengangguran sebagai masalah yang selamanya tidak dapat terpecahkan. Beranjak dari asumsi bahwa meningkatnya jumlah pengangguran disebabkan oleh sistem Pendidikan Indonenesia, maka perlu adanya program tertentu yang perlu diterapkan di perguruan tinggi sehingga bisa menjawab keberhasilan sistem pendidikan Indonesia yang pada akhirnya bisa menurunkan tingkat pengangguran di Indonesia. 
2553 Kebijakan Sistem Pendidikan Indonesia: Keterkaitan Dunia Sekolah dengan Dunia Kerja Sebuah Alternatif - Tan Gusli, Nurhizrah Gistituati, Sufyarma Marsidin

DOI: https://doi.org/10.31004/edukatif.v3i5.844

\section{METODE PENELITIAN}

Penelitian menggunakan metode kualitatif deskriftif. Pengumpulan data menggunakan sumber data primer yang diperoleh dari berbagai referensi, media online. Analisisnya adalah dengan melakukan kajian kajian literatur terhadap sistem pendidikan indonesia dan mencarikan solusi terhadap permasalahan dan menarik sebuah kesimpulan. Analisis ini dilakukan terhadap realita yang terjadi yang berangkat dari data data dan informasi yang diperoleh dari berbagai referensi. Dalam penelitian akan di fokuskan pada proram yang diterapkan oleh pergguruan dalam menjawab keterkaitan sistem pendidikan dengan tingginya tingkat pengangguran.

\section{HASIL DAN PEMBAHASAN PENELITIAN}

\section{Kebijakan Pendidikan di Indonesia}

Berbicara tentang kebijakan pendidikan di Indonesia, sebelumnya perlu disinggung sekilas tentang apa itu kebijakan. kebijakan (policy) secara etimologi diturunkan dalam bahasa Yunani, Polis yang berarti kota (city). Kebijakan mengacu kepada cara-cara dari semua bagian pemerintahan mengarahkan untuk mengelola kegiatan mereka. Kebijakan berkenaan dengan gagasan pengaturan organisasi dan merupakan pola formal yang sama-sama diterima pemerintah atau lembaga sehingga dapat mencapai tujuan organisasi (Purba, 2021).

Kebijakan atau policy secara umum sering digunakan untuk memilih dan menunjukkan pilihan terpenting dalam mempererat kehidupan, baik dalam lembaga kepemerintahan maupun swasta. Kebijakan sering digunakan untuk menunjukan perilaku seseorang yang memiliki power atau kekuasaan misalnya seorang pejabat negara, pimpinan suatu kelompok seperti organisasi masyarakat (ormas). Kebijakan (policy) sering juga diterjemahkan dengan kebijaksanaan, namun ini belum ada kesepakatan. Terlepas dari hal tersebut, kebijakan (policy) dan kebijaksanaan (wisdom) berasal dari kata dasar yang sama, yaitu bijak. Namun, secara maknawi, kebijakan dan kata bijak atau kebijaksanaan itu sendiri memiliki pengertian yang berbeda. Landasan utama suatu kebijakan adalah akal, sedangkan kebijaksanaan lebih didasarkan kepada budi manusia. Jadi, sebuah kebijakan belum tentu bijak dan kebijaksanaan belum tentu ia sebuah kebijakan.

Frederick, Davis dan Post berpendapat bahwa kebijakan pada tingkat publik ditujukan kepada tindakan yang diambil pemerintah untuk mempromosikan perhatian masyarakat banyak kebijakan publik itu mulai dari pajak, pertahanan nasional sampai perlindungan lingkungan mempengaruhi bisnis secara langsung (Purba, 2021). Sahya Anggara dalam bukunya kebijakan publik mengatakan bahwa hakikatnya kebijakan publik dibuat oleh pemerintah berupa tindakan tindakan pemerintah. Kebijakan publik, baik untuk melakukan maupun tidak melakukan sesuatu mempunyai tujuan tertentu. Kebijakan publik ditujukan untuk kepentingan masyarakat atau kepentingan umum.

Berdasarkan pendapat yang dikemukan oleh beberapa ahli di atas maka kebijakan dapat pormulasikan sebagai suatu rumusan strategi, konsep, dan model yang dibangun melalui proses analisis komprehensif guna menyelesaikan suatu permasalahan tertentu sehingga pembuat kebijakan tentu dalam hal ini adalah pemerintah dapat menentukan pilihan untuk melakukan sebuah tindakan. Sebagai konsekuensi dari pilihan tersebut, dilakukan monitoring dan evaluasi untuk menentukan arah kebijakan kebijakan selanjutnya.

Kebijakan pendidikan (educational policy) merupakan keputusan berupa pedoman bertindak baik yang bersifat sederhana maupun kompleks, baik umum maupun khusus, baik terperinci maupun longgar yang dirumuskan melalui proses politik untuk suatu arah tindakan, program, serta rencana-rencana tertentu dalam menyelenggarakan pendidikan. Kebijakan pendidikan tidak dapat dilepaskan dengan hakikat pendidikan dalam proses memanusiakan anak manusia menjadi manusia merdeka.

Arif Rahman mengatakan bahwa kebijakan pendidikan merupakan bagian dari kebijakan negara atau kebijakan publik pada umumnya. kebijakan pendidikan merupakan kebijakan publik yang mengatur khusus regulasi berkaitan dengan penyerapan sumber, alokasi dan distribusi sumber, serta pengaturan perilaku dalam 
pendidikan (Purba, 2021). Semua kebijakan pendidikan itu, tentu bukan hanya menjadi urusan segelintir orang atau masyarakat tertentu saja, melainkan sudah menjadi urusan semua pihak. Dengan demikian kebijakankebijakan yang diambil berkenaan dengan dunia pendidikan juga menjadi bagian dari produk kebijakan publik.

Sehubungan dengan kebijakan pendidikan merupakan bagian dari kebijakan publik tersebut, banyak pihak memahami bahwa kebijakan pendidikan itu sebagai kumpulan hukum atau perundangundangan yang mengatur pelaksanaan sistem pendidikan, mencakup didalamnya tujuan, proses, evaluasi dan tindak lanjut pendidikan supaya tidak terjadi benturan konflik (conflict interest) antar warga Negara dalam memenuhi hak dan kewajibannya. Dalam realitasnya dapat dilihat dari adanya pemerintah Indonesia melaksanakan kebijakan Ujian Nasional (UN), Kebijakan lima hari sekolah (Full Day School), Kebijakan Uang Kuliah Tunggal (UKT), Kebijakan pengakuan sertifikat akreditasi bagi lulusan perguruan tinggi memasuki dunia kerja. Dalam amanah Undang-undang Dasar 1945, Pasal 31 menegaskan bahwa pemerintah menempatkan pendidikan itu menjadi kewajiban pemerintah dan pemerintah daerah melaksanakan peran mendasar yakni menyediakan akses dan kesempatan belajar.

Sahya Anggara dalam bukunya kebijakan publik menyebutkan dalam analisinya terhadap kebijakan pendidikan bahwa "Indonesia sebagai negara hukum menitik beratkan pendidikan sebagai wahana memajukan negara. Dalam realitanya kebijakan demi kebijakan seperti bongkar pasang dengan dalil untuk menghasilkan kualitas pendidikan yang optimal (Anggara, 2014). hasilnya masih jauh dari yang diharapkan stakeholder. misalnya kebijakan pengalokasian pembiayaan pendidikan 20\% dari pemerintah pusat yaitu melalui Anggaran Pendapatan dan Belanja Negara (APBN) sedangkan pemerintah daerah melalui Anggaran Pendapatan dan Belanja Daerah (APBD). Dengan dalil pengeluaran gaji pendidik dan tenaga kependidikan serta tunjangan lainnya yang dimasukkan sebagai dana pendidikan, maka dinilai sudah terpenuhi komitmen tersebut. Padahal sampai saat ini kondisinya masih belum 100\% dapat terlaksana, bahkan kurikulum yang sering berubah-ubah, kebijakan ujian nasional dan lainnya. Inkonsistensi pemerintah dalam memutuskan beberapa kebijakan pendidikan nasional seringkali menimbulkan tanda tanya bahkan kontroversi pro dan kontra di tengah masyarakat dan dunia pendidikan. Tuntutan paling mendesak dalam meningkatkan mutu pendidikan dan relevan dengan dunia kerja yang semakin kompetitif adalah peningkatan kemampuan para pemangku kepentingan dalam melakukan analisis kebijakan pendidikan" (Purba, 2021).

Bentuk kepedulian pemerintah Indonesia dalam menyelenggarakan pendidikan terlihat pada besaran alokasi anggaran pendidikan yang terus mengalami peningkatan. Ini menunjukkan adanya keseriusan pemerintah dalam memberikan jaminan tiap warga negara mendapatkan pendidikan yang memadai dan berkualitas. Ini sesuai dengan tujuan pendidikan Nasional dalam UU No. 20 Tahun 2003 adalah mengembangkan kemampuan dan membentuk watak serta peradaban bangsa yang bermartabat dalam rangka mencerdaskan kehidupan bangsa, bertujuan untuk berkembangnya potensi peserta didik agar menjadi manusia yang beriman dan bertakwa kepada Tuhan Yang Maha Esa, berakhlak mulia, sehat, berilmu, cakap, kreatif, mandiri, dan menjadi warga negara yang demokratis serta bertanggung jawab. Jika kita mendapatkan pendidikan, maka kita akan mempunyai motivasi untuk menjadi seseorang yang lebih baik dalam semua aspek kehidupan. Pendidikan adalah salah satu persyaratan untuk memajukan bangsa ini sehingga pendidikan harus dimulai sejak dini mulai dari taman kanak-kanak hingga perguruan tinggi.

Moch. Surya (2004) menyatakan bahwa Undang-undang nomor 20 tahun 2003 mengandung sejumlah paradigma baru yang menjadi landasan perwujudan pendidikan nasional. Paradigma tersebut, antara lain:

1) Penyelenggaraan pendidikan nasional dilandasi dengan prinsip-prinsip berikut ini : a) Secara demokratis dengan menjunjung tinggi nilai kemanusiaan, keagamaan, dan budaya bangsa.b) Sebagai satu kesatuan yang sistemik dengan system terbuka dan multi makna. c) Sebagai proses pembudayaan dan pemberdayaan yang berlangsung sepanjang hayat. d) Sebagai proses keteladanan membangun kemauan dan kreativitas dalam proses pembelajaran.e) Mengembangkan budaya belajar (baca, tulis, dan hitung) 
2555 Kebijakan Sistem Pendidikan Indonesia: Keterkaitan Dunia Sekolah dengan Dunia Kerja Sebuah Alternatif - Tan Gusli, Nurhizrah Gistituati, Sufyarma Marsidin

DOI: https://doi.org/10.31004/edukatif.v3i5.844

bagi segenap warga masyarakat. f) memberdayakan masyarakat melalui partisipasi dan pengendalian mutu layanan pendidikan.

2) Demokratisasi dan desentralisasi sebagai semangat yang melandasi penyelenggaraan pendidikan nasional dengan lebih menekankan peran serta masyarakat dan pemerintah daerah dalam keseluruhan aktivitas penyelenggaraan pendidikan.

3) Peran serta masyarakat sebagai konsekuensi demokratisasi pendidikan nasional maka masyarakat memperoleh kesempatan yang seluas-luasnya dalam penyelenggaraan dan pengendalian mutu pelayanan pendidikan.

4) Tantangan global, hal ini berimplikasi bahwa pendidikan nasional harus beradaptasi dengan perkembangan global yang menuntut sumber daya manusia yang lebih berkualitas dalam menghadapi persaingan global di segala bidang.

5) Kesetaraan dan keseimbangan, bahwa Undang-undang Sisdiknas yang baru mengandung paradigma dengan menerapkan konsep kesetaraan dalam penyelenggaraan pendidikan yang diselenggarakan oleh pemerintah memeiliki kesetaraan dengan satuan pendidikan yang dislenggarakan oleh masyarakat (swasta). Sedangkan yang dimaksud keseimbangan ialah keseimbangan yang utuh antara unsur-unsur kepribadian yang meliputi aspek intelektual, spiritual, emosional, fisik, sosial, moral, dan kultural.

Namun sangat disayangkan sebagian besar masyarakat, menganggap pendidikan bukan menjadi hal utama dalam mewujudkan kesejahteraan hidup. Selain itu pemerintah belum maksimal mengawasi pengalokasian dana pendidikan. Realitasnya masih ada kesulitan yang dialami sebagian masyarakat yang sudah menyadari akan pentingnya pendidikan, kesulitan dalam mendapatkan fasilitas pembiayaan pendidikan. Kondisi saat ini, pendidikan kita masih terasa mahal sebagian masyarakat yang berada pada garis kehidupan di bawah garis kemiskinan. Akibatnya masih terdapat ketimpangan sosial antara sesama warga negara dalam mendapatkan layanan pendidikan. Untuk mendapatkan kualitas pendidikan yang baik, namun dirasakan mahal oleh sebagian masyarakat. Begitu juga pemerintah saat ini sudah melaksanakan program wajib belajar 12 tahun. Hal ini menjadi kecemasan warga masyarakat yang kurang mampu menyekolahkan anaknya dengan biaya mahal.

\section{Perkembangan Pendidikan Indonesia}

Sebelum melanjutkan pembahasan tentang keterkaitan pendidikan dengan dunia kerja, perlu juga dilihat bagaimana perkembangan pendidikan di Indonesia. Pendidikan di Indonesia telah mengalami masa masa perkembangan yang dalam perjalannya cukup menarik untuk dikaji, adapun dalam tulisan akan dibatasi dengan perkembangan pendidikan indonesia dari masa kolonial belanda sampai dengan sekarang:

1. Pendidikan Zaman Pergerakan: Masa Kolonial Belanda.

Pendidikan pada masa kolonialisme ini adalah cerminan dari sistem ekonomi kolonial yang bersifat penghisapan negara atas negara, penghisapan terhadap negara Indonesia. Pendidikan masa ini dirancang berdasarkan politik kolonialisme yang bersifat diskriminatif. Pendidikan dapat diklasifikasikan menjadi dua jenis yaitu pendidikan bagi kaum kolonialis dan pendidikan bagi bangsa terjajah atau kaum pribumi (Tim UNY, n.d.). Prinsip pendidikan yang diterapakan di Indonesia sebagai daerah kolonial sebagai berikut: 1). Pemerintah kolonial berusaha tidak memihak salah satu agama tertentu. 2). Pendidikan diarahkan agar para tamatannya menjadi pencari kerja, terutama demi kepentingan kaum penjajah. 3). Sistem persekolahan disusun berdasarkan stratifikasi sosial yang ada dalam masyarakat. 4). Pendidikan diarahkan untuk membentuk golongan elite-sosial (penjilat penjajah) Belanda. 5). Dasar pendidikannya adalah dasar pendidikan Barat dan berorientasi pada pengetahuan dan kebudayaan Barat. Berdasarkan dari prinsip inilah pemerintah Hindia Belanda menerapkan kebijakan bahwa kesempatan mendapatkan pendidikan diutamakan pada anak anak bangsawan bumi putera serta tokoh-tokoh terkemuka dan pegawai kolonial yang diharapkan 
kelak mereka akan menjadi penyambung tangan-tangan penjajah sebagai upaya Belanda untuk memerintah secara tidak langsung kepada masyarakat dan bangsa Indonesia.

Di zaman kolonialisme, pendidikan untuk anak anak Indonesia memang sangat terbatas sehingga ada banyak penduduk Indonesia yang masih buta huruf. Pendidikan pada masa ini lebih fokus untuk menanamkan semangat patriotisme.

2. Pendidikan Indonesia Menjelang Masa Kemerdekaan: Pendidikan Masa Penjajahan Jepang.

Pendidikan yang diselenggarakan oleh pemerintah Jepang saat itu dijiwai oleh semangat militer Jepang. Pendidikan yang didasari oleh pendidikan militer, diawali dengan dilakukannya banyak perubahan terhadap pendidikan di Indonesia saat itu. Sifat dualisme pendidikan yang sebelumnya telah lama melekat pada sistem penyelenggaraan pendidikan masa kolonial Belanda dengan sistem pendidikannya yang berlapis-lapis berusaha dihapuskan, kemudian diganti dengan sistem pendidikan yang lebih sederhana. Pendidikan yang diselenggarakan oleh pemerintah Jepang dijiwai oleh semangat militer Jepang. Dalam menerapkan kebijakan pendidikannya, guna memperoleh dukungan tokoh pribumi, Jepang mengawalinya dengan menawarkan konsep Putera (Pusat Tenaga Rakyat) di bawah pimpinan Sukarno, M. Hatta, Ki Hadjar Dewantoro, dan K.H. Mas Mansur pada Maret 1943.

Secara konkrit tujuan pendidikan pada zaman Jepang ini adalah menyediakan tenaga kerja secara cumacuma yang disebut romusha dan prajurit-prajurit untuk membantu peperangan demi kepentingan Jepang, maka para pelajar diwajibkan mengikuti latihan fisik, latihan kemiliteran, dan indoktrinasi ketat. Hal ini terbukti dengan pelaksanaan senam pagi yang disebut taiso sebelum belajar juga bagi para pegawai sebelum kerja mengikuti komando dengan radio. Mengikuti latihan kemiliteran yang disebut kyoren bagi para pelajar dengan barisannya yang disebut Seinendan, barisan keamanan rakyat yang disebut Keibodan dan barisan prajutit yang disebut Heiho (Intan Printina, 2019).

3. Pendidikan Zaman Orde Lama: Dari Kolonialistik Sampai Nasionalistik

Pendidikan pada masa ini dirumuskan untuk mendidik warga negara seutuhnya, diharapkan bersedia menyumbangkan tenaga dan pikiran untuk negara dan masyarakat. Tujuan pendidikan pada masa itu penekanannya pada penanaman semanagat patriotisme. Penanaman semangat patriotisme sebagai tujuan pendidikan memang sesuai dengan situasi pada waktu itu. Negara dan bangsa Indonesia sedang mengalami perjuangan fisik dan sewaktu-waktu pemerintah kolonial Belanda masih berusaha untuk menjajah kembali negara Indonesia. Maka dengan semangat itu, kemerdekaan dapat di pertahankan dan diisi.

Ada suatu kebanggaan pada masa Orde Lama ini Indonesia mampu mengekspor lulusan pendidikan guru ke negara tetangga, dan banyak generasi muda yang disekolahkan di luar negeri dengan tujuan agar mereka kelak dapat kembali ke tanah air untuk mengaplikasikan ilmu yang telah mereka dapat di luar negeri untuk bangsa Indonesia.

4. Pendidikan Zaman Orde Baru: Penguatan Demokrasi Pancasila

Tujuan pendidikan nasional yang pertamakali ditetapkan sejak era Orde Baru berkuasa di Indonesia adalah melalui Ketetapan MPRS Nomor XXVII Tahun 1966 Bab II Ayat 3. Di dalamnya disebutkan bahwa tujuan utama pendidikan di Indonesia adalah untuk mempersiapkan manusia yang berjiwa Pancasila sebagaimana yang tertuang dalam pembukaan UUD 1945. melalui Garis-Garis Besar Haluan Negara (GBHN) tahun 1973 ditegaskan bahwa tujuan pendidikan nasional adalah "membentuk manusiamanusia pembangunan yang berjiwa Pancasila untuk membentuk manusia Indonesia yang sehat jasmani dan rohani, memiliki pengetahuan dan keterampilan, dapat mengembangkan kreativitas dan tanggungjawab, dapat mengembangkan kecerdasan yang tinggi dan disertai budi pekerti yang luhur, mencintai bangsanya dan mencintai sesama manusia sesuai dengan ketentuan yang termaktub dalam UUD 1945. Pemerintah Orde Baru berpijak pada Pancasila dan UUD 1945 untuk mewujudkan tujuan pendidikan nasional. Hal tersebut tampaknya diterapkan sebagai antitesis landasan pendidikan Indonesia pada masa Orde Lama yang dinilai oleh rezim Orde Baru terkontaminasi ide dan gagasan yang disisipi pemikiran berpaham sosialisme (Safei; Hudaidah, 2020). 
Target minimal pembangunan pendidikan di era Orde Baru adalah terbentuknya pengetahuan dan kemampuan dasar seperti membaca, menulis, berhitung, dan penggunaan bahasa Indonesia (Ali, 2009). Dengan bahasa lain, pendidikan pada masa Orde Baru bertujuan untuk menghasilkan manusia-manusia Indonesia yang berdayaguna dan pada akhirnya nanti mampu menggerakkan roda perekonomian negara. Pada masa ini, pemerintah ingin memberikan kesempatan belajar yang lebih luas namun juga harus diimbangi dengan kualitas pendidikan tersebut. Pendidikan tinggi harus dapat menjawab tantangan dunia modern. Sistem pendidikan pada masa itu berhubungan dengan kualifikasi dan pengembangan kesempatan untuk pembangunan nasional.

\section{Masa Reformasi}

Kebijakan Pendidikan yang menjadi objek perbaikan dalam sistem Pendidikan nasional terdiri dari empat program kebijakan yaitu peningkatan mutu pendidikan; efisiensi pengelolaan pendidikan; relevansi pendidikan; serta pemerataan pelayanan pendidikan. Keempat program tersebut dilandasi kepada keinginan dan tuntutan bangsa Indonesia berkaitan dengan peningkatan kualitas serta mempermudah dan mempercepat pelayanan di bidang pendidikan (Mukodi, 2016).

Selain itu, pada masa ini pemerintah melakukan perubahan yang revolusioner seperti mengubah kurikulum pendidikan. Kurikulum Berbasis Kompetensi (KBK) membuat siswa harus lebih aktif untuk mendapatkan informasi. Kurikulum Tingkat Satuan Pendidikan (KTSP) mirip dengan KBK tetapi ada perbedaan pada kewenangan untuk menyusun kurikulum tersebut yakni desentralisasi sistem pendidikan sehingga guru harus mengembangkan pengajaran yang sesuai dengan kondisi sekolah. Periode ini semangat desentralisasi, demokratisasi, dan globalisasi yang dibawa oleh gerakan reformasi sehingga penataan sistem pendidikan nasional menjadi menu utama.

6. Masa sekarang: era globalisasi

Pendidikan di era globalisasi menekankan adanya suatu perubahan radikal dalam bingkai pendidikan di Indonesia sehingga bisa menikmati yang namanya peradaban baru dalam dunia pendidikan. Terobosan baru itu adalah melalui penerapan kurikulum 2013. Kurikulum 2013 bertujuan untuk mempersiapkan manusia Indonesia agar memiliki kemampuan hidup sebagai pribadi dan warga negara yang beriman, produktif, kreatif, ifovatif, dan afektif serta mampu berkontribusi pada kehidupan bermasyarakat, berbangsa, bernegara, dan berandil dalam peradaban dunia (Permendikbud RI No. 67 Tahun 2013). Pengembangan Kurikulum 2013 dilakukan karena ada tantangan internal maupun eksternal (Novendi Abdi, 2021).

Pemerintah telah merespon globalisasi secara terbuka melalui Pasal 50 ayat 3 UU No. 20 Tahun 2003 tentang Sistem Pendidikan Nasional (UU Sisdiknas) yang berbunyi: Pemerintah dan/atau Pemerintah Daerah menyelenggarakan sekurang-kurangnya satu-satuan pendidikan pada semua jenjang pendidikan untuk dikembangkan menjadi satuan pendidikan yang bertaraf internasional. Berdasar azas legalitas ketentuan UU Sisdiknas ini, menjamurlah berbagai SBI (Sekolah Bertaraf Internasional) di semua kabupaten/kota dalam Indonesia.

Globalisasi, menimbulkan dampak bagi pendidikan Indonesia disamping dampak posititif juga ada dampak negatif yang harus di antisipasi oleh pemerintah, diantara dampak negatif dari era globalisasi ini adalah: pertama, dunia pendidikan akan menjadi objek komoditas dan komersil seiring dengan kuatnya hembusan paham neoliberalisme yang melanda dunia. Paradigma dalam dunia komersil adalah usaha mencari pasar baru dan memperluas bentuk-bentuk usaha secara terus menerus. Globalisasi mampu memaksa liberalisasi berbagai sektor yang dulunya non-komersial menjadi komoditas dalam pasar yang baru. Tidak heran apabila sekolah masih membebani orang tua murid dengan sejumlah anggaran berlabel uang komite atau uang sumbangan pembangunan institusi meskipun pemerintah sudah menyediakan dan Bantuan Operasional Sekolah (BOS). Kedua, mulai melemahnya kekuatan kontrol pendidikan oleh Negara. Tuntutan untuk berkompetisi dan tekanan institusi global, seperti International Monetary Fund (IMF) dan World Bank, mau atau tidak, membuat dunia politik dan pembuat kebijakan harus berkompromi untuk melakukan 
perubahan. Lahirnya UUD 1945 yang telah diamandemenkan, UU Sisdiknas, dan PP No. 19 tahun 2005 tentang Standar Nasional Pendidikan (SNP) setidaknya telah membawa perubahan paradigma pendidikan dari corak sentralistis menjadi disentralistis. Ketiga, globalisasi akan mendorong delokasi dan perubahan teknologi dan orientasi pendidikan. Pemanfaatan teknologi baru, seperti komputer dan internet, telah membawa perubahan yang sangat revolusioner dalam dunia pendidikan yang tradisional. Pemanfaatan multimedia yang portable dan menarik sudah menjadi pemandangan yang biasa dalam praktik pembelajaran didunia sekolah Indonesia. Disinilah bahwa pendidikan menjadi agenda prioritas kebangsaan yang tidak bisa ditunda-tunda lagi untuk dilakukan seoptimal mungkin (Rusniati, 2015).

\section{Pendidikan Indonesia: Keterkaitan dunia sekolah dengan dunia Kerja}

Berdasarkan UU No. 13 tahun 2003 Bab I pasal 1 ayat 2 disebutkan bahwa tenaga kerja adalah setiap orang yang mampu melakukan pekerjaan guna menghasilkan barang atau jasa baik untuk memenuhi kebutuhan sendiri maupun untuk masyarakat. Tenaga kerja disini tentu adalah penduduk Indonesia yang berada dalam usia kerja. Salah satu tujuan dari orang tua menyekolahkan anaknya sampai ke Perguruan Tinggi tak lain adalah agar anaknya mendapatkan pendidikan dan pekerjaan yang layak. Walaupun dalam kenyataannya masih banyak lulusan perguruan tinggi atau sekolah menengah atas di Indonesia yang tidak memiliki pekerjaan atau pengangguran. Karena memang persaingan tenaga kerja begitu ketat ditambah lagi ketersedian lapangan pekerjaan belum seimbang dengan jumlah lulusan sekolah perguruan tinggi.

Masa transisi dari dunia pendidikan ke dunia kerja seharusnya mendapat perhatian penuh oleh pemerintah Indonesia dan ini harus ditangani secara inovatif dan dalam penangannya tentunya berkolaboratif dengan seluruh pemangku kepentingan. Pendidikan adalah titik awal masa masa taransisi antara dunia sekolah dengan dunia kerja. Dengan pendidikan seharusnya seseorang bisa menentukan sejauhmana mereka siap bekerja.

Merunut kebelakang bahwa pendidikan dalam pandangan tradisional dipahami sebagai bentuk pelayanan sosial yang harus diberikan kepada masyarakat. Konteks ini, pelayanan pendidikan sebagai bagian dari public service atau jasa layanan umum dari negara kepada masyarakat yang tidak memberikan dampak langsung bagi perekonomian masyarakat sehingga pembangunan pendidikan tidak menarik untuk menjadi tema perhatian. Kedudukannya tidak mendapat perhatian menarik dalam gerak langkah pembangunan. Tentunya cara pandang seperti sudah mulai tergusur sejalan dengan ditemukannya pemikiran dan bukti ilmiah akan peran dan fungsi vital pendidikan dalam memahami dan memposisikan manusia sebagai kekuatan utama sekaligus prasyarat bagi kemajuan pembangunan dalam berbagai sektor. Konsep pendidikan sebagai sebuah investasi (education as investement) telah berkembang secara pesat dan semakin diyakini oleh setiap negara bahwa pembangunan sektor pendidikan merupakan prasyarat kunci bagi pertumbuhan sektor-sektor pembangunan lainnya.

Konsep tentang investasi sumber daya manusia yang dapat menunjang pertumbuhan ekonomi telah mulai dipikirkan, misalnya Adam Smith, Heinrich Von Thunen, dan para teoritisi klasik lainnya sebelum abad ke 19 yang menekankan pentingnya investasi keterampilan manusia. Dalam teori ekonomi klasik, human capital yang berupa kemampuan dan kecakapan yang diperoleh melalui pendidikan, belajar sendiri, dan belajar sambil bekerja. Pendidikan seperti ini tentunya memerlukan biaya yang besar. Pendekatan human capital ini terlihat hubungan yang linier antara investasi di bidang pendidikan dengan produktivitas. Manusia sebagai modal dasar yang diinvestasikan akan menghasilkan manusia terdidik yang produktif dan meningkatnya penghasilan sebagai akibat dari kualitas kerja (Smith, 2007).

Sebelum ada pendidikan melalui sekolah seperti sekarang, pendidikan dijalankan secara spontan dan langsung dalam kehidupan sehari-hari. Anak-anak petani langsung mempelajri pertanian dengan langsung bekerja di sawah, anak-anak nelayan langsung mempelajari kelautan dan perikanan langsung mengikuti orang dewasa menangkap ikan. Selagi mempelajari pekerjaan yang dilakukan, mereka sekaligus juga belajar tentang 
nilai-nilai dan norma-norma yang berhubungan dengan pekerjaannya. Dilihat dari sisi ini, pendidikan pada dasarnya merupakan sesuatu yang kongkret, spontan, dan tidak direncanakan tetapi langsung berhubungan dengan keperluan hidup. Dengan kata lain, dalam situasi yang belum mengenal sistem sekolah, sifat pendidikan pada dasarnya sesalu bersifat keterkaitan antara pendidikan dengan pekerjaan.

Konsep keterkaitan antara dunia pendidikan dan dunia kerja yang pernah dicetuskan oleh mantan Mendiknas Prof. Dr. Wardiman perlu dihidupkan lagi. Konsep itu bisa menekan jumlah pengangguran lulusan perguruan tinggi yang dari ke hari makin bertambah. Soemarso, Ketua Dewan Pembina Politeknik dan juga dosen UI mengatakan bahwa konsep keterkaitan antara lembaga pendidikan dan dunia kerja dianggap ideal. Jadi, ada keterkaitan antara pemasok tenaga kerja dengan penggunanya. Menurut Soemarso, dengan adanya hubungan timbal balik membuat perguruan tinggi dapat menyusun kurikulum sesuai dengan kebutuhan kerja. Contoh nyatanya adalah dengan program magang. Perbaikan magang, dimaksudkan agar industri juga mendapatkan manfaat. Selama ini ada kesan yang mendapatkan manfaat dari magang adalah perguruan tinggi dan mahasiswa, sedangkan industri kebagian repotnya (Ardiansyah, 2011).

Di sisi lain, produk dari Perguruan Tinggi menghasilkan sesuatu yang amat berharga dan bukan hanya sekedar kertas tanpa makna, yaitu produk kepakaran, produk pemikiran dan kerja laboratorium. Produkproduk ini masih sangat jarang dilirik oleh industri di Indonesia. Produk kepakaran yang sering dipakai adalah yang bersifat konsultatif. Tetapi produk hasil laboratorium belum di akomodasi dengan baik. Jika kita bicara soal kesempatan kerja, maka di negara Indonesia jika ada satu pekerjaan maka diperkirakan ada seribu orang yang akan melamar. Dari seribu orang itu mungkin hanya sekitar seratus orang yang memenuhi persyaratan administrasi dan lulus test psikologi. Intinya begitu besar gap atau perbedaan antara Supply and Demand, antara persyaratan kerja dengan mereka yang memenuhi kualifikasi persyaratan kerja tersebut.

\section{Solusi sebagai Pendekatan dalam Mewujudkan Keterkaitan dunia pendidikan dengan dunia kerja}

Menarik apa yang disampaikan oleh para pakar ekonomi, Becker, Ehrenberg \& Smith, Doyle \& Weale, Elaug, sebagaimana yang disampaikan oleh goldy Dharmawan dalam tulisannya Lika Liku Arah Kebijakan Pendidikan Indonesia pendidikan sebagai investasi dalam pembangunan manusia. Pendidikan yang berkualitas akan meningkatkan produktivitas tenaga kerja dan secara simultan juga berpotensi untuk meningkatkan kesejahteraan tenaga kerja. Selain itu, pendidikan juga memiliki eksternalitas positif terhadap angka kelahiran dan pertumbuhan ekonomi. Meski pengaruh pendidikan terhadap pertumbuhan ekonomi dan perilaku masyarakat bersifat tidak langsung, hasil dari investasi pendidikan dapat diukur dengan menghitung manfaat sosial yang diterima oleh masyarakat.

Sebagai ilustrasi dalam mencarikan solusi tentang keterkaitan dunia pendidikan dengan dunia kerja bagi anak bangsa di Indoseia adalah kebijakan pendidikan di Jerman, untuk pendidikan kejuruan, Kamar Dagang dan Industri Jerman memegang peranan sangat besar. Pemerintah memberikan kewenangan kepada kamar dagang dan industri Jerman untuk membuat kurikulum, menyediakan tempat magang, menyediakan para trainer atau pengajar dan juga assesornya. Segala sesuatu yang berhubungan dengan materi ajar, penguji, pengajar dan evaluasi sekolah kejuruan ditangani oleh kamar dagang dan industri Jerman. Ssistem ganda pada sekolah kejuruan di Jerman, mengajarkan teori sekitar $20 \%$ di sekolah dan $80 \%$ nya adalah magang dengan bimbingan para supervisor di industri.Tidak heran lulusan SMK otomotif misalnya langsung mendapatkan pekerjaan di perusahaan otomotif. Biasanya mereka langsung diterima bekerja diperusahaan tempat mereka magang. Dengan magang langsung di industri, semua peralatan dan kebutuhan perusahaan selalu up to date, tidak ada perbedaan anatara alat peraga yang ada di sekolah dengan yang ada di industri. Ilustrasi ini memang pada tataran konsep kebijakan dualisme pendidikan antara dunia sekolah dengan dunia kerja. Tapi setidaknya ini bisa diambil sebagai pedoman dalam mengatasi persoalan pengangguran intelektual.

Berangkat dari hal itu, setidaknya ada tiga komponen yang harus bergerak simultan untuk menyukseskan program keterkaitan antara pendidikan yaitu perguruan tinggi, dunia kerja (perusahaan) dan 
pemerintah. Dari ketiga komponen tersebut, peran perguruan tinggi merupakan keharusan dan syarat terpenting. Kreativitas, inovasi dan kecerdasan pengelola perguruan tinggi menjadi faktor penentu bagi sukses tidaknya program tersebut. Ada beberapa langkah penting yang harus dilakukan suatu perguruan tinggi untuk menyukseskan program ini.

1. Perguruan tinggi harus mau melakukan riset ke dunia kerja.

Riset ini dilakukan untuk mengetahui sejauhmana kompentensi atau keahlian apa yang paling dibutuhkan dunia kerja dan kompetensi apa yang paling banyak dibutuhkan dunia kerja. Dalam hal ini tentu yang sangat berperan dan harus menjadi kajian para pengelola perguruan Tinggi adalah menyusun kurikulum yang berbasis kompetensi. Kurikulum merupakan kata kunci dalam menyelaraskan antara dunia pendidikan dengan dunia kerja. Institusi dan pemangku kebijakan perguruan harus merevisi kurukulum menjadi kebutuhan dunia kerja.

Perguruan tinggi harus menjadikan kompetensi yang dibutuhkan dunia kerja sebagai materi kuliah di kampusnya. Dengan demikian, diharapkan, lulusan perguruan tinggi sudah mengetahui, minimal secara teori, tentang kompetensi apa yang dibutuhkan setelah mereka lulus. Meskipun demikian, perguruan tinggi tidak harus menyesuaikan seluruh materi kuliahnya dengan kebutuhan dunia kerja. Sebab, harus ada materi kuliah yang berguna bagi mahasiswa yang termotivasi untuk melanjutkan studi ke jenjang strata yang lebih tinggi.

2. Menjalin Relasi atau mitra Hubungan dengan banyak perusahan

Perguruan tinggi harus menjalin relasi atau mitra hubungan dengan banyak perusahaan sebagai arena belajar kerja atau magang bagi mahasiswa yang akan lulus. Dengan program magang ini mahasiswa tidak hanya siap secara teori tetapi juga siap secara praktik. Karena itu, tentunya pemerintah secara serius menjaga keterkaitan implementasi ilmu dari perguruan tinggi ke dunia kerja. Tentunya semua pihak stake holders diharapkan bersedia membuka diri menjalankan program ini.

3. Membuat bank data kebutuhan dunia kerja dan kelulusan.

Perguruan tinggi harus menyusun data terkait dengan kelulusan mahasiswa dan diselaraskan dengan kebutuhan dunia kerja. Data ini harus betul betul dikelola dengan baik dalan bank data. Melalui bank data ini tentu harapannya adalah ada data yang betul betul valid dan mumpuni untuk memberikan prediksi tentang kompetensi apa yang paling dibutuhkan oleh dunia kerja.

4. Kewirausahaan dijadikan Muatan Lokal

Perguruan tinggi menjadikan kewirausahaan sebagai muatan lokal, dan ini memang perlu keseriusan pengelola. Melalui pelatihan kewirausahaan yang berbasis potensi lokal, ini bisa menjadi salah satu solusi dalam mendorong jiwa kewirausahaan para peserta didik dan bisa menjadi bekal bagi para lulusan dalam menghadapi dunia pasar bebas. Setidaknya melalui program kewirausahaan ini para lulusan akan mampu dalam Menularkan dan mengembangkan semangat berwirausaha kepada orang lain dan dapat berkreasi dan berinovasi dalam menciptakan lapangan kerja sendiri.

Pemerintah tentu tidak mungkin secara serta merta bisa mempersiapkan berbagai kelembagaan pendidikan untuk mempersipakan lulusannya yang siap pakai memasuki lapangan kerja yang sudah menunggu. Ini memang melalui proses yang panjang. Karena memang dalam banyak faktor pendukung harus disiapkan bukan hanya biaya, tapi lebih dari itu pengadaan tenaga instruktur yang berkualifikasi baik, juga menyiap tenaga tenag yang komten dalam menjawab tantangan ini. Dengan ini diharapkan akan ada titik singgung antara pendidikan dan dunia kerja yang akan bisa melahirkan produktivitas kerja. Dengan begitu juga bisa menjawab pendidikan seyokyan bisa menurunkan tingkat pengangguran di Indonesia. 
2561 Kebijakan Sistem Pendidikan Indonesia: Keterkaitan Dunia Sekolah dengan Dunia Kerja Sebuah Alternatif - Tan Gusli, Nurhizrah Gistituati, Sufyarma Marsidin

DOI: https://doi.org/10.31004/edukatif.v3i5.844

\section{KESIMPULAN}

Hasil penelitian menunjukkan bahwa perlunya penerapan program melalui perguruan tinggi sebagai lembaga pendidikan dengan (1) Perguruan tinggi harus mau melakukan riset ke dunia kerja. (2). Menjalin relasi atau mitra hubungan dengan banyak perusahan (3). Membuat bank data kebutuhan dunia kerja dan kelulusan. (4). Kewirausahaan dijadikan muatan lokal

Dengan kebijakan tersebut Perguruan Tinggi dapat mengetahui kompentensi apa yang paling dibutuhkan dunia kerja dan kompetensi apa yang paling banyak dibutuhkan dunia kerja.

\section{UCAPAN TERIMA KASIH}

Terima kasih saya sampaikan kepada insteri tercinta, ananda, dosen pembimbing, dan sahabat sahabat mahasiswa S3 Administrasi Publik yang memberikan saran dan masukan terhadap tulisan. Sungguh tak ada gading yang tak retak, tulisan ini belumlah sempurna masih banyak kekurangan karena memang harus diakui keterbatasan referensi yang penulis miliki

\section{DAFTAR PUSTAKA}

Ali, M. (2009). Pendidikan Untuk Pembangunan Nasional Menuju Bangsa Indonesia Yang Mandiri Dan Berdaya Saing Tinggi. Imtima.

Anggara, S. (2014). Kebijakan Publik. Bandung: Pustaka Setia.

Ardiansyah, A. (2011). Konsep Link And Match Dalam Pendidikan.

C. Frederick, W. K. (1998). Business And Siciety, Coeporate Strategy, Public Policy, Ethics. New York: Mcgraw-Hill Publishing Company.

Enoch, J. (1992). Dasar-Dasar Perencanaan. Jakarta: Bumi Aksara.

Hasibuan, S. (1987). Changing Manpower Requirements In The Face Of Non-Oil Growth, Labor Force Growth And Fast Technological Change. Jakarta: Bappenas.

Intan Printina, B. (2019). Membumikan Moral Dan Cinta Benih Bangsa. Deepublish.

Isjoni. (2006). Pendidikan Sebagai Investasi Masa Depan. Yayasan Obor Indonesia.

Koontz, H. W. (1993). Management A. Global Perspevtive Tent Edition. New York: Mcgraw-Hill.

Mukodi. (2016). Refleksi Dinamika Kebijakan Pendidikan Di Indonesia. Ikatan Sarjana Pendidikan Indionesia Jawa Tengah, Volume 3 N, 12. Spijateng.Org/Wp-Content/Uploads/2017/02/Mukodi-141152.Pdf

Novendi Abdi, G. (2021). Transformasi Pendidikan Di Era Globalisasi.

Purba, S. (2021). Analisis Kebijakan (R. Watrianthos (Ed.)). Yayasan Kita Menulis.

Rusniati. (2015). Pendidikan Nasional Dan Tantangan Globalisasi. Jurnal Ilmiah DIDAKTIKA, Vol 16 No., $105-128$.

Rohman, A. (2009). Politik Ideologi Pendidikan. Yogyakarta: Mediautama.

Sa'ud, U. S. (2006). Perencanaan Pendidikan Suatu Pendekatan Komprehensif. Bandung: Remaja Rosdakarya.

Safei; Hudaidah. (2020). Sistem Pendidikan Umum Pada Masa Orde Baru (1968-1998). Jurnal Humanitas, Vol 7 No 1. Https://E-Journal.Hamzanwadi.Ac.Id/

Smith, A. (2007). An Inquiry Into The Nature And Causes Of The Wealth Of Nations (S. Marcelo Soares (Ed.)). Metalibri. Https://Metalibri.Incubadora.Fapesp.Br 
2562 Kebijakan Sistem Pendidikan Indonesia: Keterkaitan Dunia Sekolah dengan Dunia Kerja Sebuah Alternatif - Tan Gusli, Nurhizrah Gistituati, Sufyarma Marsidin

DOI: https://doi.org/10.31004/edukatif.v3i5.844

Statistik, B. P. (2020). Berita Resmi Statistik. No. 85/11/, 51.

Suryadi, A. D. (1993). Analisis Kebijakan Pendidikan: Suatu Pengantar . Bandung: Rosdakarya.

Syafril; Zen, Z. (2017). Dasar Dasar Ilmu Pendidikan. Kencana.

Tim UNY. (N.D.). Peta Jalan Pendidikan Indonesia. 